\title{
Trends in fertility rates, proportion of antenatal consultations and caesarean sections among Brazilian adolescents
}

\author{
Tendência das taxas de fertilidade, proporção de consultas de prénatal e cesarianas entre adolescentes brasileiras
}

Tendencias de las tasas de fertilidad, proporción de consultas de prenatal y cesarianas entre adolescentes brasileñas

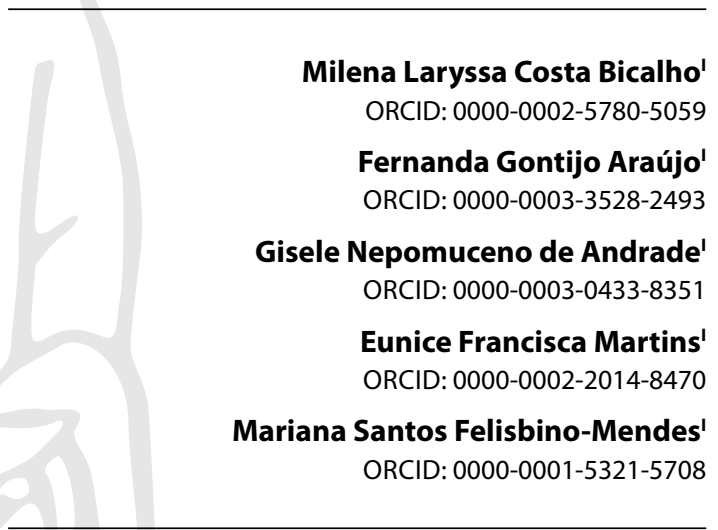

'Universidade Federal de Minas Gerais. Belo Horizonte, Minas Gerais, Brazil.

How to cite this article: Bicalho MLC, Araújo FG, Andrade GN, Martins EF, FelisbinoMendes MS. Trends in fertility rates, proportion of antenatal consultations and caesarean sections among Brazilian adolescentes. Rev Bras Enferm. 2021;74(Suppl 4):e20200884. https://doi.org/10.1590/0034-7167-2020-0884

\section{Corresponding author:}

Mariana Santos Felisbino-Mendes E-mail: marianafelisbino@yahoo.com.br

EDITOR IN CHIEF: Antonio José de Almeida Filho ASSOCIATE EDITOR: Alexandre Balsanell

Submission: 09-05-2020 Approval: 11-11-2020

\section{ABSTRACT}

Objective: To analyze the temporal trends in the fertility rate, proportion of antenatal consultations and caesarean sections in Brazilian adolescents aged 15 to 19, between 2000 and 2015. Methods: The fertility rate, proportion of prenatal consultations and proportion of routes of birth were calculated using data from DATASUS. The trend analysis was performed using the Prais-Winsten regression model and the annual percentage change. Results: There was a trend of reduction of $3.5 \%$ per year in the fertility rate among adolescents $(p<0.05)$, in addition to an increasing trend of $6 \%$ per year in the proportion of more than six antenatal consultations $(p<0.0001)$ and an increasing trend of $6.8 \%$ per year in the proportion of caesarean sections $(p<0.0001)$. Conclusion: Despite the decreasing trend in fertility rates among Brazilian adolescents, they remain high. Also noteworthy is the growing trend for caesarean sections, even with improved access to antenatal care.

Descriptors: Pregnancy in Adolescence; Birth Rate; Prenatal Care; Caesarean Section; Time Serie Studies.

\section{RESUMO}

Objetivo: Analisar as tendências temporais da taxa de fertilidade, proporção de consultas de prénatal e cesarianas em adolescentes brasileiras de 15 a 19 anos, entre 2000 e 2015 . Métodos: A taxa de fertilidade, proporção de consultas de pré-natal e proporção de vias de nascimento foram calculadas com dados do DATASUS. A análise de tendência foi realizada utilizando-se o modelo de regressão de Prais-Winsten e a taxa de variação média anual. Resultados: Observou-se tendência de redução de 3,5\% ao ano da taxa de fertilidade entre as adolescentes $(p<0,05)$, além de tendência crescente de $6 \%$ ao ano da proporção de mais de seis consultas de pré-natal $(p<0,0001)$ e tendência crescente de $6,8 \%$ ao ano da proporção de cesarianas $(p<0,0001)$. Conclusão: Apesar da tendência decrescente da taxa de fertilidade nas adolescentes brasileiras, elas ainda permanecem elevadas. Destaca-se também a tendência crescente de cesarianas, mesmo com a melhoria do acesso ao pré-natal. Descritores: Gravidez na Adolescência; Coeficiente de Natalidade; Cuidado Pré-Natal; Cesárea; Estudos de Séries Temporais.

\section{RESUMEN}

Objetivo: Analizar las tendencias temporales de la tasa de fertilidad, proporción de consultas de prenatal y cesarianas en adolescentes brasileñas de 15 a 19 años, entre 2000 y 2015. Métodos: La tasa de fertilidad, proporción de consultas de prenatal y proporción de vías de nacimiento fueran calculadas con datos del DATASUS. Análisis de tendencia realizada utilizándose modelo de regresión de Prais-Winsten y la tasa de variación media anual. Resultados: Observó tendencia de reducción de 3,5\% al año de la tasa de fertilidad entre las adolescentes $(p<0,05)$, además de tendencia creciente de $6 \%$ al año de la proporción de más de seis consultas de prenatal $(p<0,0001)$ y tendencia creciente de $6,8 \%$ al año de la proporción de cesarianas $(p<0,0001)$. Conclusión: Aunque la tendencia decreciente de la tasa de fertilidad en adolescentes brasileñas, ellas aún permanecen elevadas. Destaca también la tendencia creciente de cesarianas, mismo con la mejoría del acceso al prenatal. Descriptores: Embarazo en la Adolescencia; Coeficiente de Natalidad; Cuidado Prenatal; Cesárea; Estudios de Series Temporales. 


\section{INTRODUCTION}

Adolescence comprises the phase of life between childhood and youth, from 10 to 19 years old, divided into the stages of pre-adolescence (10 to 14 years old) and adolescence ( 15 to 19 years old), characterized by the search for autonomy over decisions, actions and emotions, for the development of skills and the experience of sexuality ${ }^{(1)}$. This search and experimentation can expose adolescents to violence and risky behaviours, resulting in their greater susceptibility to sexually transmitted infections (STIs) and unplanned pregnancies ${ }^{(1)}$.

In this context, teenage pregnancy is a worldwide problem, being more frequent in low and middle income countries and commonly driven by poverty, low education and lack of job opportunities $^{(2)}$. In these countries, a total of 23 million pregnant adolescents are estimated, $91.3 \%$ of whom are 15 to 19 years old, and $8.7 \%$ are under 15 years old ${ }^{(2-3)}$. In Latin America and the Caribbean, there is an estimate that, each year, $15 \%$ of pregnancies occur in adolescents under the age of 20 and 2 million children are born to mothers aged 15 to 19 years ${ }^{(3)}$.

In Brazil, the fertility rate of adolescents aged 15 to 19 years is above the Latin American and Caribbean average ${ }^{(3)}$. In 2010, births to women under 20 years of age represented almost $20 \%$ of the total in the country, being higher in the poorest regions, such as the North and North-east ${ }^{(4)}$. In addition, between 2000 and 2012, fertility rates for adolescents aged 10 to 14 years in Brazil remained high and stable ${ }^{(5)}$.

Pregnancy can result in several negative repercussions for adolescents and their children, with complications of pregnancy and childbirth being the main cause of death among women aged 15 to 19 worldwide, and children born to adolescent mothers are those who have higher risks of prematurity, low birth weight and severe neonatal conditions ${ }^{(3)}$. It is estimated that about 3.9 million unsafe abortions occur each year among girls aged 15 to 19 , contributing to maternal mortality and long-term health problems ${ }^{(2)}$.

Adolescent pregnancy is also associated with a lower educational level and can contribute to the perpetuation of the cycle of poverty from one generation to another ${ }^{(6)}$. Therefore, preventing unplanned pregnancies can have long-term benefits for adolescents, their children and society ${ }^{(2)}$. In Brazil, despite the implementation of public sexual and reproductive health policies for adolescents, they are still ineffective, which contributes to the increased vulnerability of this group to STIs and unplanned pregnancies. In 2019, the proposal of a policy that is based exclusively on the promotion of sexual abstinence among young people ${ }^{(7)}$ reinforces this fragility and the consequences of conservatism in restricting rights and better health outcomes for this population, especially girls and women.

It is also known that adolescents do not attend health services; and when they look for them, the most common reason is related to unplanned pregnancy. In addition, health services often fail to address adolescent demands ${ }^{(8)}$. To aggravate the situation, many pregnant adolescents late seek health services because they want to hide their condition ${ }^{(9)}$, or because they do not know what to do or where to seek care ${ }^{(8)}$. Thus, adequate health care for pregnant adolescents is impaired, which contributes to the unfavourable results.
Studies show less adequacy of antenatal care among adolescents, and this affects complications and higher rates of maternal and child morbidity and mortality ${ }^{(8,10)}$. Additionally, when compared to mothers aged 20 or over, adolescents have fewer antenatal consultations and caesarean sections ${ }^{(10)}$. Furthermore, it is observed that the performance of caesarean section in adolescents can result in obstetric complications ${ }^{(10)}$. Thus, among the benefits of adequate antenatal care, the mediating action for the choice and indication of the mode of delivery stands out, as, during consultations, guidance on the parturition process and beneficial practices during labor should be offered ${ }^{(11)}$, which could contribute to better decisions for pregnant women and the health team.

Adolescence still constitutes a period in the life cycle neglected by public health policies in Brazil ${ }^{(8)}$, mainly in the context of sexual and reproductive health. In addition, studies on teenage pregnancy are limited by several aspects: for example, they address very early pregnancy, in girls under 15 years old ${ }^{(5)}$, with local $^{(10)}$ or regional ${ }^{(12)}$ samples, evidencing the need for national studies that address the temporal evolution of pregnancy indicators in adolescents aged 15 to 19 , such as access to antenatal care and childbirth and birth and possible regional differences. It is believed that evaluating the trends of these indicators at the national and regional level could elucidate scenarios of greater vulnerability and support planning of interventions according to the local reality.

\section{OBJECTIVE}

To analyze the temporal trends of the fertility rate, proportion of antenatal and caesarean sections in Brazilian adolescents aged 15 to 19 years, between 2000 and 2015 .

\section{METHODS}

\section{Ethical aspects}

Ethical recommendations regarding the conduct of the study were followed in accordance with Resolution No. 466, of 12 December 2012 $2^{(13)}$, of the National Health Council, which does not require approval by the ethics committee for studies using data secondary, aggregated, without identifying the subjects and available from public sources, as in the case of the present study, whose data were obtained from the Informatics Department of the Unified Health System (DATASUS), the Live Birth Information System (SINASC) and the Brazilian Institute of Geography and Statistics (IBGE).

\section{Study design, period and location}

It is an observational, retrospective, time series study, guided by the Strengthening the Reporting of Observational Studies in Epidemiology (STROBE) tool and based on secondary data extracted from DATASUS, SINASC and IBGE.

\section{Population}

The population consisted of Brazilian adolescents aged 15 to 19 and their respective live births from 2000 to 2015, considering all of Brazil and, separately, each of its five regions. 


\section{Study protocol}

Data were collected from DATASUS. In DATASUS, SINASC was used, from which the numbers of live births, live births by caesarean sections, vaginal or ignored birth and number of antenatal consultations of adolescents aged 15 to 19 years were extracted, in each year of the period of 2000 to 2015, considering all of Brazil and each of its regions. The population number of adolescents aged 15 to 19 was extracted from IBGE, for Brazil and regions. For the years 2000 and 2010, data from demographic censuses were used; for the period from 2001 to 2009, 2011 and 2012, population estimates were applied; and from 2013 to 2015, population projections were used, as the estimates were not stratified by age and sex. The data were obtained in July 2017 and are publicly available on the DATASUS website. (http://www2.datasus.gov.br/ DATASUS/index.php). Information on the source and methodology used by IBGE can also be consulted at: http://tabnet.datasus. gov.br/cgi/lbge//popdescr.htm.

\section{Data analysis and statistics}

The fertility rate, the proportion of antenatal consultations and mode of delivery for adolescents aged 15 to 19 years were calculated for each year of the study period, for the whole of Brazil and for each of the five regions (North, Northeast, Southeast, South and Midwest).

The fertility rate was calculated using the registered number of live births of adolescents aged 15 to 19 years old each year (data from SINASC) as a numerator and the estimated number of adolescents aged 15 to 19 years old each year (IBGE data) as the denominator, the result of this division being multiplied by a thousand. To calculate the proportion of antenatal consultations, the number of antenatal consultations per indicator $(0,1-3,4-6$ and 7 or more) was used as a numerator; and, as a denominator, the live births of adolescents aged 15 to 19 years, for each year of the period studied, the result being multiplied by one hundred. The proportion of mode of delivery was calculated in the same way, obtaining the percentage of a specific birth (vaginal, caesarean or ignored) in relation to the total births for the age group of interest.

Then, the trend analysis of the fertility rate, the proportion of antenatal consultations (greater than or equal to seven consultations) and the proportion of caesarean sections among adolescents was carried out. The generalized linear regression model by Prais-Winsten ${ }^{(14)}$ was used in the Time Series module of the Stata program, version 14.0. Then, the annual percentage change (APC) and their respective $95 \%$ confidence intervals (95\% Cl) were calculated, obtained from the regression coefficients. It is noteworthy that, for the fertility rate, the trend analysis was carried out in three periods ( 2000 to 2015, 2000 to 2006 and 2007 to 2015) since a different behaviour was observed in the periods from 2000 to 2006 and 2007 to 2015.

\section{RESULTS}

During the period studied, there were a total of 9,482,182 live births to women aged 15 to 19 years, which represents $19.9 \%$ of all
$47,715,968$ births in the country (data not shown). Figure 1 shows fertility rates in adolescents aged 15 to 19 years for Brazil and regions. In Brazil, in 2000, the rate was 80.9 births per thousand adolescents; and, in 2015, it was 61.8 per thousand, showing a reduction of $23.6 \%$. The highest rates were found in the North of the country, with 111.6 births per thousand adolescents in 2000 and 90.7 per thousand in 2015. The lowest rates were found in the Southeast Region, 71.4 births per thousand adolescents in 2000 and 51.9 per thousand in 2015. It is observed that, in three of the five regions of the country, fertility rates were higher than the country's average, being North, Northeast and Midwest. In addition, there was an evident decrease in rates until 2006; and, after this year, there is a relative maintenance of fertility rates among adolescents (Figure 1).

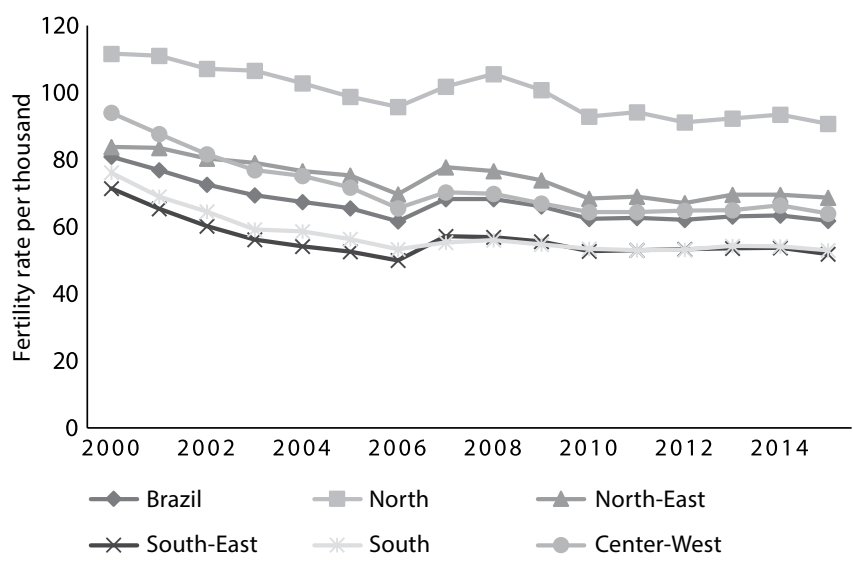

Figure 1 -Temporal evolution of the fertility rate among adolescents aged 15 to 19 years, Brazil and regions, 2000-2015

The trend analysis showed that fertility rates among adolescents aged 15 to 19 years showed a statistically significant reduction trend for Brazil and all regions, reducing an average of 3.5\% per year, with this decrease varying between regions. The greatest reduction was observed in the Midwest Region (5.42\%); and the lowest, in the North Region (3.06\%) (Table 1).

The analysis of Figure 1 shows a greater reduction until the year 2006 , so it was decided to carry out the trend analysis in two periods: from 2000 to 2006 and from 2007 to 2015. The analysis of Figure 1 shows a greater reduction until the year 2006, so it was decided to carry out the trend analysis in two periods: from 2000 to 2006 and from 2007 to 2015. It can be said that the Southeast (APC $=-12.7 \%)$, South (APC $=-12.3 \%$ ) and Center-West $(A P C=-12.2 \%)$ Regions had the highest reduction rates when compared to North (APC $=-5.9 \%$ ) and Northeast (APC $=-6.2 \%$ ). In the period from 2007 to 2015, the trend towards a statistically significant reduction continued for Brazil and all regions, except for the South Region $(p=0.087)$, which remained stable. During this period, there was an average annual reduction lower than that observed in the period from 2000 to 2006 (APC $=-2.8 \%$ ), which was also observed in the Southeast $($ APC $=-2.5 \%)$ and Midwest Regions (APC $=-2.4 \%$ ). On the other hand, in this interval, the highest rates of reduction were found in the North $(-3.7 \%)$ and Northeast $(-3.5 \%)$, which is the opposite of what was observed for 2000 to 2006 (Table 1). 
Table 1 - Trends in fertility rate, proportion of seven or more antenatal consultations and proportion of caesarean sections among Brazilian adolescents aged 15 to 19 years, $2000-2015$

\begin{tabular}{|c|c|c|c|c|c|c|c|c|c|c|}
\hline \multirow{3}{*}{ Regions } & \multirow{2}{*}{\multicolumn{4}{|c|}{ Fertility rate }} & \multirow[b]{2}{*}{ 2007-2015 } & \multicolumn{3}{|c|}{$\begin{array}{l}\text { Proportion of seven } \\
\text { or more antenatal } \\
\text { consultations }\end{array}$} & \multicolumn{2}{|c|}{$\begin{array}{c}\text { Proportion of } \\
\text { caesarean sections }\end{array}$} \\
\hline & & & & & & & 2000-2015 & & 2000-2015 & \\
\hline & $\operatorname{APC}^{1}(\mathrm{Cl} 195 \%)^{2}$ & $p$ value & APC (Cl95\%) & $p$ value & APC (C195\%) & $p$ value & APC (CI95\%) & $p$ value & APC (Cl95\%) & $p$ value \\
\hline Brazil & $-3.50(5.28 ; 1.69)$ & 0.001 & $-9.56(-10.8 ;-8.32)$ & $<0.0001$ & $-2.80(-4.93 ;-0.62)$ & 0.021 & $5.99(5.50 ; 6.48)$ & $<0.0001$ & $6.81(4.33 ; 9.35)$ & $<0.0001$ \\
\hline North & $-3.06(-4.14 ;-1.97)$ & $<0.0001$ & $-5.87(-7.13 ;-4.60)$ & $<0.0001$ & $-3.75(-6.09 ;-1.34)$ & 0.009 & $9.31(6.25 ; 12.45)$ & $<0.0001$ & $8.49(5.99 ; 11.05)$ & $<0.0001$ \\
\hline North-east & $-3.16(-4.22 ;-2.08)$ & $<0.0001$ & $-6.23(-7.20 ;-5.24)$ & $<0.0001$ & $-3.53(-6.57 ;-0.40)$ & 0.036 & $9.09(6.71 ; 11.52)$ & $<0.0001$ & $11.29(8.11 ; 14.57)$ & $<0.0001$ \\
\hline South-east & $-3.89(-6.79 ;-0.90)$ & 0.015 & $-12.68(-15.81 ;-9.44)$ & $<0.0001$ & $-2.51(-4.23 ;-0.76)$ & 0.013 & $5.31(3.00 ; 7.66)$ & $<0.0001$ & $3.93(1.68 ; 6.23)$ & 0.002 \\
\hline South & $-5.23(-8.57 ;-1.77)$ & 0.007 & $-12.32(-15.43 ;-9.09)$ & $<0.0001$ & $-1.18(-2.53 ; 0.19)$ & 0.087 & $6.37(3.31 ; 9.52)$ & $<0.0001$ & $6.31(3.96 ; 8.71)$ & $<0.0001$ \\
\hline Center-west & $-5.42(-8.00 ;-2.77)$ & 0.001 & $-12.17(-13.94 ;-10.37)$ & $<0.0001$ & $-2.43(-4.62 ;-0.19)$ & 0.041 & $3.20(1.94 ; 4.48)$ & $<0.0001$ & $6.89(4.95 ; 8.86)$ & $<0.0001$ \\
\hline
\end{tabular}

Note: ${ }^{1} A P C$ : annual percentage change; ${ }^{2} \mathrm{C} 195 \%: 95 \%$ confidence interval

Regarding the number of antenatal consultations carried out by Brazilian adolescents aged 15 to 19 in different regions of Brazil, there was an increase in the proportion of seven or more consultations in all regions, varying from $36.6 \%$ in 2000 to $54.9 \%$ in 2015 for the whole country (Figure 2), representing an increase of $50 \%$. The highest proportions of seven or more consultations were in the South and Southeast, with $44.9 \%$ and $45.2 \%$ in 2000 and $67.7 \%$ and $63.6 \%$ in 2015 , respectively. The lowest proportions of this indicator were in the North Region, $21.3 \%$ in 2000 and $38.2 \%$ in 2015 (Figure 2).

In the North Region, despite the increase in the proportion of seven or more consultations, the highest proportions remained in the indicator of four to six antenatal consultations, with $45.6 \%$ in 2000 and $40.4 \%$ in 2015 (Figure 2). There was a growing and statistically significant trend in the proportion of seven or more antenatal visits to Brazil and its regions, with an average increase of $6 \%$ per year (Table 1). As for the Brazilian average, the Midwest Region showed the smallest increase in this proportion $(A P C=3.2 \%)$, while the North $(A P C=9.3 \%)$ and Northeast $(A P C=9.1 \%$ ) regions showed the highest percentage of increase (Table 1). Despite this, these regions still showed the lowest proportions of antenatal visits compared to other Brazilian regions in 2015.

The proportions of the different mode of delivery among adolescents aged 15 to 19 years in Brazil and regions were also assessed, from 2000 to 2015 (Figure 3). In Brazil and in its different regions, the largest proportion of the way of birth was for vaginal delivery, but there was an increase in the proportion of caesarean sections over the period.

In Brazil, the proportions of caesarean sections were $26.3 \%$ in 2000 and $39.3 \%$ in 2015 among adolescents, representing an increase of $49.4 \%$. The highest proportions of caesarean sections occurred in the Midwest Region, with 31.2\% in 2000 and $46.2 \%$ in 2015; and the smallest, in the Northeast Region, with proportions of $18.5 \%$ in 2000 and $36.3 \%$ in 2015 . The increase in the proportion of caesarean sections was statistically significant for Brazil and all regions, with an average increase of $6.8 \%$ per year, varying between regions. In relation to the national average, the Northeast Region presented the greatest increase in caesarean sections (APC $=11.3 \%$ ); and the Southeast Region, the smallest increase $(A P C=4 \%)$ (Table 1$)$.

\section{DISCUSSION}

The results of the present study showed that fertility rates had a trend towards a statistically significant decreasing during the period from 2000 to 2015 , with this decreasing being more accentuated in the period from 2000 to 2006. In addition, there was a trend towards an increase in the proportion of seven or more antenatal consultations and an increasing trend in the proportion of caesarean sections among Brazilian adolescents aged 15 to 19 years in the study period, in Brazil and regions.

WHO estimates also show that the global fertility rate among adolescents aged 15 to 19 fell from 65 births per thousand women in 1990 to 46 births per thousand women in $2015^{(3)}$. A study that analyzed the trend of teenage pregnancy in 16 countries also showed a reduction in this indicator since the $1990 \mathrm{~s}^{(15)}$. Among the countries analyzed, the lowest teenage pregnancy rates were observed in Switzerland (8 per thousand adolescents), the Netherlands, Singapore and Slovenia (14 per thousand adolescents), while the highest rates were in sub-Saharan African countries, varying between 121 per thousand in Ethiopia to 187 per thousand adolescents in Burkina Faso ${ }^{(15)}$. Among the countries of America, the estimates of the United States (57 per thousand adolescents) and Mexico (130 per thousand adolescents) stand out, with high rates of teenage pregnancies ${ }^{(15)}$. Thus, despite being a problem that occurs in high, middle- and low-income countries, it is more frequent in low- and middle-income countries, such as Brazil.

Our country maintains high fertility rates among adolescents compared to the world average and with other regions of the world, but has managed to advance in relation to the countries of the Southern Cone (Argentina, Chile, Brazil, Paraguay and Uruguay) in terms of the trend of a constant reduction of the fertility rate in adolescence in the first decade of the 21 st century, whereas, in other countries, these trends were irregular, with slight increases and falls ${ }^{(3)}$.

The high fertility rates among Brazilian adolescents are related to specific factors such as low socioeconomic and educational levels ${ }^{(5,16-17)}$. The adolescents' fertility rate was previously shown to be inversely proportional to social status, income and education $^{(10,12,17)}$. In the present study, the highest fertility rates were among adolescents who lived in less economically favored areas and with the worst social and educational conditions in 

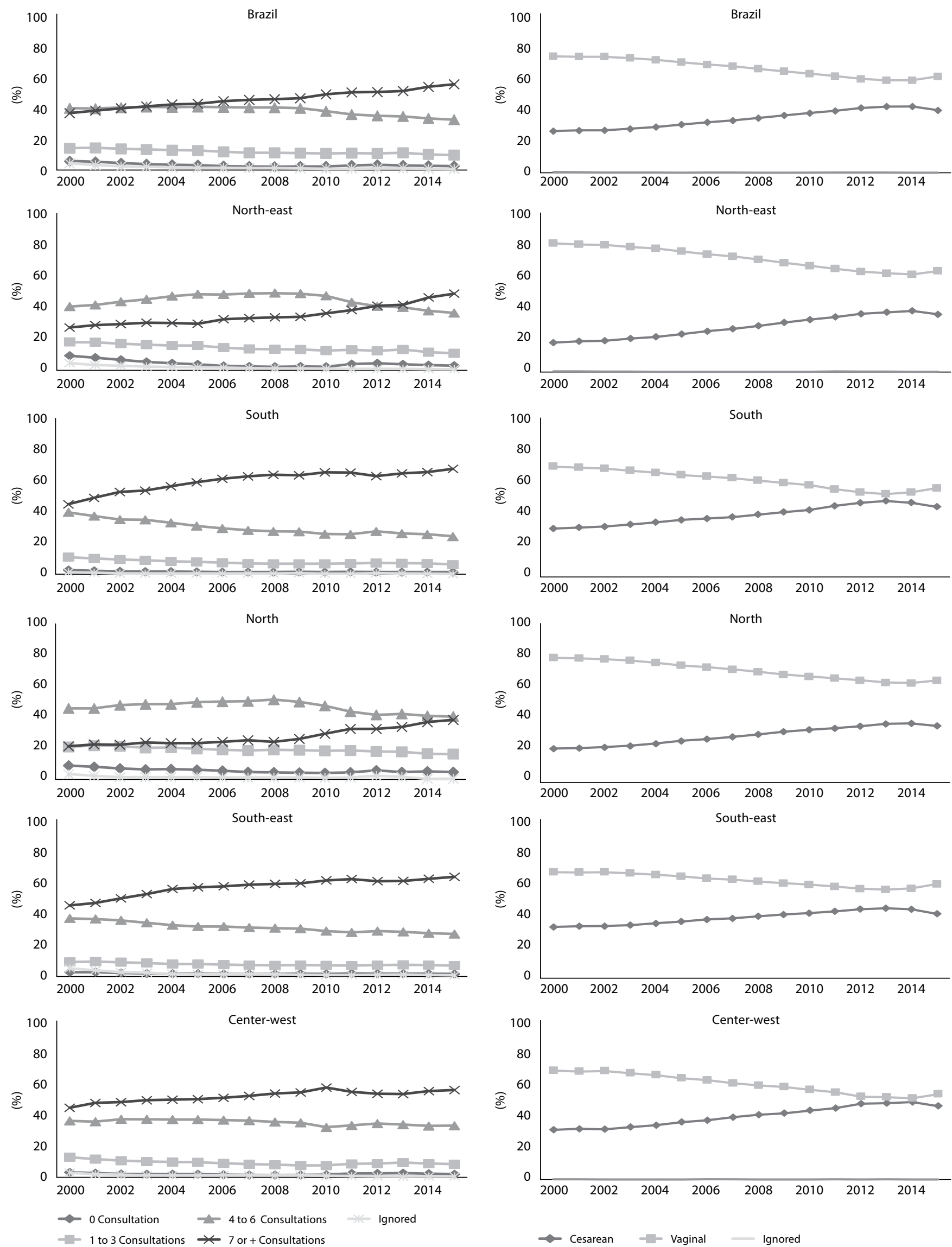

Figure 2 - Temporal evolution of the proportion of antenatal consultations among adolescents aged 15 to 19 years, Brazil and regions, 2000-2015

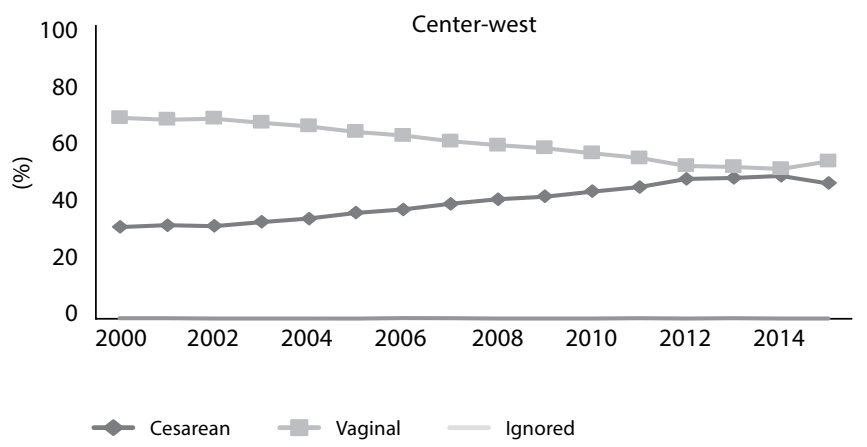

Figure 3 - Temporal evolution of the proportion of mode of delivery among adolescents aged 15 to 19 years, Brazil and regions, 2000-2015 
the country, in addition to high gender inequality, such as the North and Northeast Regions, indicating that characteristics of the environment also could influence this outcome, corroborating other studies ${ }^{(5,1216-18)}$. Furthermore, a previous study showed that the Brazilian regions (Southeast, South and Center-South), with the highest human development index (HDI), had lower rates of live births to adolescent mothers ${ }^{(17)}$.

Regarding the greatest reduction in the fertility rate in the period from 2000 to 2006, it is believed that the regulation of the Unified Health System (SUS), the creation of the Family Health Strategy (FHS), the Child and Adolescent Statute (ECA) and programs and strategies to meet the needs of adolescents, such as the Adolescent Health Program (PROSAD), may have contributed to this result ${ }^{(19)}$. In this scenario, the creation and frank expansion of the Family Health Strategy (FHS) stands out, which increased the population's access to health services, including family planning and antenatal care ${ }^{(20-21)}$. Other strategies were created to facilitate adolescents' access to health services, such as the Health at School Program (PSE), however, health professionals were unprepared and health services were disqualified for care and targeted actions. to the adolescent public, especially regarding sexuality and reproduction ${ }^{(9)}$, in addition to difficulties in implementing and continuing public policies aimed at this specific population ${ }^{(19)}$. All of this may have contributed to reducing the decline in the teenage pregnancy rate and worsening sexual and reproductive health indicators in this population. As a challenge, we highlight the need to understand teenage pregnancy in addition to social and public health aspects, an understanding of the phenomenon as a subjective experience and in the context of the adolescent's personality formation ${ }^{(22)}$.

A recent study with data from the National School Health Survey showed a worsening of indicators related to sexual and reproductive health in this portion of the population, such as reduced condom use, greater vulnerability to sexually transmitted infections and higher occurrence of pregnancy among adolescents in public schools ${ }^{(23)}$. Thus, the current scenario is worrying, with uncertain future prospects, in view of the growing ultraconservative political and social context in the country, with a political movement to reduce access to family planning, especially for this group ${ }^{(16)}$.

Another result exposed by the present study was that of improving access to antenatal consultations among adolescents. Since the 1990s, there has been an increase in coverage of antenatal care ${ }^{(20)}$, reaching values above $90 \%$ in all Brazilian regions and in women with different sociodemographic and reproductive characteristics ${ }^{(21)}$. This high coverage can be explained by the strategies implemented by the Ministry of Health, such as the FHS, the creation of the National Program for Humanization in Antenatal and Birth (PHPN) and the Stork Network ${ }^{(20-21)}$. Although there has been an increasing trend in the proportion of seven or more consultations, studies show that the highest proportion of inadequate antenatal care, such as late start and inadequate number of consultations, occurs among adolescents, especially those with less education and low socioeconomic status, when compared to adult pregnant women ${ }^{(24-26)}$. A study that evaluated the antenatal care of pregnant adolescents in Brazil showed that $84.4 \%$ received inadequate care during antenatal period, with worse results for those of lower economic class, black/brown, with inadequate schooling for their age, who lived in the North and Northeast Regions and who were multiparous ${ }^{(26)}$, corroborating the regional inequalities of access found in this study.

There was also an increasing and alarming trend in the proportion of caesarean sections among adolescents aged 15 to 19 years in Brazil and regions. Caesarean section has shown an increasing global trend, causing an increase in the costs of health services and in the risks of maternal and perinatal morbidity and mortality, with Brazil being the country with the highest rate of caesarean sections in the world ${ }^{(27-28)}$. The increase in the proportion of caesarean sections is also related to the interventionist pattern of obstetric care observed in the country ${ }^{(4,27)}$, which is known to lead to a higher incidence of obstetric complications ${ }^{(10)}$. It is worth highlighting the relevance of this finding, since it is about young women, with a higher probability of new caesarean sections in future pregnancies. Ratifying this statement, studies indicate that, despite scientific evidence, in Brazil the precept that "once caesarean, always caesarean" is still followed ${ }^{(11)}$.

Still, it is emphasized that access to caesarean section goes beyond the clinical indication and the preference of women ${ }^{(4)}$, being a procedure influenced by the care received in antenatal period $^{(4,10)}$, the source of payment for delivery and socioeconomic factors ${ }^{(4)}$. Previous studies have shown that adolescents are statistically less likely to have caesarean sections compared to adult women ${ }^{(10,24)}$; however, in this study, there was an important increase in the proportion of caesarean sections in this group, paradoxically to the same extent that access to antenatal care is increased, which in summary seeks to reduce risks during pregnancy. Considering the technocratic model, this situation could be partially explained by the belief that teenage mothers have an increased risk of vaginal delivery due to aspects related to gynaecological immaturity, anatomical problems linked to the delivery mechanism, which would determine a greater occurrence of cephalopelvic disproportion ${ }^{(29)}$, which can lead to a false indication for caesarean section or indication without scientific evidence. Among other causes for this increase in caesarean sections, we can mention: lack of guidance on the possible consequences of the procedure, worse socioeconomic conditions, primiparity, unpreparedness of health professionals and absence of obstetric nurses to assist delivery ${ }^{(4,10-11,28)}$.

Thus, despite the improvement in antenatal care coverage, adequate care with the provision of minimum procedures recommended by the Ministry of Health does not yet occur uniformly in the country ${ }^{(21,25)}$, especially in more vulnerable populations, such as adolescents. A recurrent failure has been the lack of adequate information about mode of delivery ${ }^{(4,27)}$, or unsatisfactory information ${ }^{(11)}$. Regardless of the source of payment for delivery and parity, women's preference for vaginal delivery has not been supported or encouraged by health professionals, and pregnant women are subjected to a model of care that makes vaginal delivery a painful experience ${ }^{(11)}$. Thus, this interventionist context of assistance to the puerperal pregnancy cycle in Brazil, added to the issues inherent to adolescence itself, which make them more vulnerable in a decision-making process, could explain the growing and alarming trend of caesarean sections in this population group. 
Finally, this study showed important results on the trend of teenage pregnancy in Brazil, as well as gaps in the assistance provided to adolescents in the puerperal pregnancy cycle. The repercussions of this phenomenon in their lives are highlighted, since pregnancy in this age group can maintain or perpetuate the intergenerational cycles of poverty, exclusion and marginalization, as many of the adolescents who become pregnant have already dropped out of school or are evaded, that significantly impacts your long-term education and work opportunities ${ }^{(4,24,30)}$.

Another worrying factor in this context is that worldwide it has been observed that the lack of formal and structured sexual education by schools and parents is implicated in the process. Brazil has faced a wave of important conservatism, which has pushed these agendas away from schools and created spaces for setbacks, such as curbing these themes for religious reasons or gender bias. A campaign was recently launched in the country with the motto "adolescence first, pregnancy later"(7), in order to make adolescents and their parents aware of the risks and consequences of teenage pregnancies; however, one of the main recommendations of the campaign is to delay the beginning of sexual relations, an approach that is considered ineffective when it occurs in isolation ${ }^{(7)}$.

\section{Study limitations}

As a limitation of this study, the fact that fertility rates and not the pregnancy rate among adolescents was analyzed and presented. Thus, the rates could be slightly higher than those presented, since pregnancies that ended in abortion or stillbirth were not included, since SINASC excludes these pregnancies. The results found regarding the proportions of antenatal consultations and caesarean sections may be underestimated for the same reason. It is also worth mentioning that another limiting factor is the population estimates used in the denominators to calculate the fertility rate. Many of these population figures are estimates based on population censuses in 2000 and 2010, which could underestimate or overestimate the values found. However, these limitations would not affect the results of the trend analysis.

\section{Contributions to the area of Nursing, Health or Public Policy}

Analyzing the trend in the fertility rate, antenatal consultations and types of delivery in adolescents aged 15 to 19 years old, it was possible to identify important gaps in relation to sexual and reproductive health services for adolescents, as well as to support the implementation of public policies aimed at reducing teenage pregnancy.

\section{CONCLUSION}

Despite the decreasing trend in fertility rates among Brazilian adolescents aged 15 to 19 , the decline is slow, and rates are still very high, with important regional inequalities. Furthermore, our findings showed the need to evaluate and improve the quality of antenatal care offered to this group, because, even with the increase in the proportion of seven or more antenatal consultations, there is an increasing trend for caesarean sections. In view of the scenario found, there is a need for greater visibility to the problem of teenage pregnancy, including aspects of the quality of care, in view of the increasing number of caesarean sections, and especially strategies and effective policies to prevent this outcome and ensure sexual and reproductive rights of this entire population.

\section{REFERENCES}

1. World Health Organization (WHO). Adolescent health [Internet]. 2020[cited 2020 Oct 09]. Available from: https://www.who.int/ health-topics/adolescent-health\#tab=tab_3

2. Darroch JE, Woog V, Bankole A, Ashford LS. Adding it up: costs and benefits of meeting the contraceptive needs of adolescents[Internet]. Guttmacher Institute. 2016 [cited 2020 Jul 23]. Available from: https://www.guttmacher.org/report/adding-it-meeting-contraceptive-needs-of-adolescents

3. United Nations Population Fund (UNFPA). Accelerating progress toward the reduction of adolescent pregnancy in Latin America and the Caribbean [Internet]. 2016 [cited 2020 Jul 23]. 55p. Available from: https://iris.paho.org/bitstream/handle/10665.2/34493/9789275119761eng.pdf?sequenc $=1$ \&isAllowed $=y \& u a=1$

4. Gama SGN, Viellas EF, Schilithz AOC, Filha MMT, Carvalho ML, Gomes KR, et al. Fatores associados à cesariana entre primíparas adolescentes no Brasil, 2011-2012. Cad Saúde Pública . 2014;30(Suppl1):S117-S127. https://doi.org/10.1590/0102-311X00145513

5. Borges AL, Chofakian CB, Sato AP, Fujimori E, Duarte LS, Gomes MN. Fertility rates among very young adolescent women: temporal and spatial trends in Brazil. BMC Pregnancy Childbirth. 2016;16:57. https://doi.org/10.1186/s12884-016-0843-x

6. Merrick TW. Making the case for investing in adolescent reproductive health: a review of evidence and PopPov Research Contributions. Population and Poverty Research Initiative and Population Reference Bureau[Internet]. 2015[cited 2020 Jul 23]. Available from: https://www. prb.org/wp-content/uploads/2016/01/poppov-report-adolescent-srh.pdf

7. The Lancet (Editorial). Preventing teenage pregnancies in Brazil. Lancet. 2020;395(10223):468. https://doi.org/10.1016/S0140-6736(20)30352-4

8. Nunes BP, Flores TR, Duro SMS, Saes MO, Tomasi E, Santiago AD, et al. Utilização dos serviços de saúde por adolescentes: estudo transversal de base populacional, Pelotas-RS, 2012. Epidemiol Serv Saúde. 2015;24(3):411-20. https://doi.org/10.5123/S1679-49742015000300007

9. Sena Filha VLM, Castanha AR. Profissionais de unidades de saúde e a gravidez na adolescência. Psicol Soc. 2014;26(nspe):79-88. https://doi. org/10.1590/S0102-71822014000500009

10. Souza ML, Lynn FA, Johnston L, Tavares ECT, Brüggemann OM, Botelho LJ. Fertility rates and perinatal outcomes of adolescent pregnancies: a retrospective population-based study. Rev Latino-Am Enfermagem. 2017;25:e2876. https://doi.org/10.1590/1518-8345.1820.2876 
11. Domingues RMSM, Dias MAB, Nakamura-Pereira M, Torres JA, Orsi E, Pereira APE, et al. Processo de decisão pelo tipo de parto no Brasil: da preferência inicial das mulheres à via de parto final. Cad Saúde Pública. 2014;30(Suppl1):S101-S116. https://doi. org/10.1590/0102-311X00105113

12. Roza DL, Oliveira CMT, Pina MFRP, Melo VDMVM, Martinez EZ. Spatio-temporal trends in the risk of adolescent pregnancy in Minas Gerais, Brazil, 2000-2015. Int J Adolesc Med Health. 2018. https://doi.org/10.1515/ijamh-2018-0027

13. Ministério da Saúde (BR). Conselho Nacional de Saúde. Resolução CNS n 466, de 12 de Dezembro de 2012. Dispõe sobre diretrizes e normas regulamentadoras de pesquisas envolvendo seres humanos[Internet]. 2012 [cited 2020 Jul 18]. Available from: https://bvsms.saude. gov.br/bvs/saudelegis/cns/2013/res0466_12_12_2012.html

14. Antunes JLF, Cardoso MRA. Uso da análise de séries temporais em estudos epidemiológicos. Epidemiol Serv Saúde. 2015;24(3):565-76. https://doi.org/10.5123/S1679-49742015000300024

15. Sedgh G, Finer LB, Bankole A, Eilers MA, Singh S. Adolescent pregnancy, birth, and abortion rates across countries: levels and recent trends. J Adolesc Health. 2015;56(2):223-30. https://doi.org/10.1016/j.jadohealth.2014.09.007

16. Câmara SM, Sentell T, Bassani DG, Domingues MR, Pirkle CM. Strengthening health research capacity to address adolescent fertility in Northeast Brazil. J Glob Health. 2019;9(1):010303. https://doi.org/10.7189/jogh.09.010303

17. Monteiro DLM, Martins JAFS, Rodrigues NCP, Miranda FRD, Lacerda IMS, Souza FM, et al. Adolescent pregnancy trends in the last decade. Rev Assoc Med Bras. 2019;65(9):1209-15. https://doi.org/10.1590/1806-9282.65.9.1209

18. Zangiacomi EM, Roza DL. Ecological analysis of adolescent birth rates in Brazil: Association with Human Development Index. Women Birth 2020;33(2):e191-e198. https://doi.org/10.1016/j.wombi.2019.04.002

19. Jager ME, Batista FA, Perrone CM, Santos SS, Dias, ACG. O adolescente no contexto da saúde pública brasileira: reflexões sobre o PROSAD. Psicol Estud. 2014;19(2):211-21. https://doi.org/10.1590/1413-737221567004

20. Leal MC, Szwarcwald CL, Almeida PVB, Aquino EML, Barreto ML, Barros F, et al . Saúde reprodutiva, materna, neonatal e infantil nos 30 anos do Sistema Único de Saúde (SUS). Ciênc Saúde Coletiva. 2018;23(6):1915-28. https://doi.org/10.1590/1413-81232018236.03942018

21. Viellas EF, Domingues RMSM, Dias MAB, Gama SGN, Filha MMT, Costa JV, et al. Assistência pré-natal no Brasil. Cad Saúde Pública. 2014;30(Suppl1):S85-S100. https://doi.org/10.1590/0102-311X00126013

22. Martins LWF, Frizzo GB, Diehl AMP. A constelação da maternidade na gestação adolescente: um estudo de casos. Psicol USP. 2014;25(3):294306. https://doi.org/10.1590/0103-656420130029

23. Felisbino-Mendes MS, Paula TF, Machado IE, Oliveira-Campos M, Malta DC. Análise dos indicadores de saúde sexual e reprodutiva de adolescentes brasileiros, 2009, 2012 e 2015. Rev Bras Epidemiol. 2018;21(Suppl1):e180013. https://doi.org/10.1590/1980-549720180013.supl.1

24. Azevedo WF, Diniz MB, Fonseca ESVB, Azevedo LMR, Evangelista CB. Complicações da gravidez na adolescência: revisão sistemática da literatura. Einstein (São Paulo). 2015;13(4):618-26. https://doi.org/10.1590/S1679-45082015RW3127

25. Domingues RMSM, Viellas EF, Dias MAB, Torres JA, Theme-Filha MM, Gama SGN, et al. Adequação da assistência pré-natal segundo as características maternas no Brasil. Rev Panam Salud Publica [Internet]. 2015 [cited 2020 Jul 20];37(3):140-7. Available from: https://www. scielosp.org/article/rpsp/2015.v37n3/140-147/\#

26. Almeida AHV, Gama SGN, Costa MCO, Viellas EF, Martinelli KG. Desigualdades econômicas e raciais na assistência pré-natal de grávidas adolescentes, Brasil, 2011-2012. Rev Bras Saude Matern Infant. 2019;19(1):43-52. https://doi.org/10.1590/1806-93042019000100003

27. Oliveira RR, Melo EC, Novaes ES, Ferracioli PLRV, Mathias TAF. Factors associated to caesarean delivery in public and private health care systems. Rev Esc Enferm USP. 2016;50(5):733-40. https://doi.org/10.1590/S0080-623420160000600004

28. Höfelmann DA. Tendência temporal de partos cesáreos no Brasil e suas Regiões: 1994 a 2009. Epidem Serv Saúde [Internet]. 2012 [cited $2020 \mathrm{Jul}$ 20];21(4):561-8. Available from: http://scielo.iec.gov.br/pdf/ess/v21n4/v21n4a05.pdf

29. Santos NLAC, Costa MCO, Amaral MTR, Vieira GO, Bacelar EB, Almeida AHV. Gravidez na adolescência: análise de fatores de risco para baixo peso, prematuridade e cesariana. Ciênc Saúde Coletiva. 2014;19(3):719-26. https://doi.org/10.1590/1413-81232014193.18352013

30. Marteleto LJ, Villanueva A. The educational consequences of adolescent childbearing and union formation in Brazil. Stud Fam Plann. 2018;10.1111/sifp.12071. https://doi.org/10.1111/sifp.12071 